\title{
ANALISIS KINERJA PERUSAHAAN PRE-SEASONED EQUITY OFFERINGS
}

\author{
Heni Kurniawan \\ Ch. Rusiti \\ Universitas Atma Jaya Yogyakarta
}

\begin{abstract}
The aim of this research is to prove whether earnings management persists in prior to Seasoned Equity Offerings (SEO) at the Jakarta Stock Exchange. This research is conducted by comparing financial performances during periods before SEO of companies which execute seasoned equity offerings to those which did not. Samples for this research are companies listed in the Jakarta Stock Exchange during 1997 2002.

The hypothesis for this research is that the financial performances of companies executing SEO is higher than those companies not executing SEO. Proxy for SEO is the event of right issue. Current Ratio $(C R)$, Debt Equity Ratio (DER), Return On Investment (ROI) ratio, Net Profit Margin (NPM) ratio, and Operating Profit Margin (OPM) ratio are used to assess financial performance. 47 companies make the sample of companies executing SEO during 1997 - 2002. For comparison, non-SEO companies are chosen from companies of similar industries and size as those of SEO companies.

This research provides evidence that, on average, performances of companies executing SEO are higher than those companies not executing SEO, even though the difference is statistically insignificant. The conclusion for this research is that there are no significant financial performance differences between SEO companies and non SEO companies in the period prior to SEO. The indications of earnings management in the event of SEO is found in a small numbers of companies.
\end{abstract}

Keywords: Seasoned Equity Offerings, Right Issue, Earnings Management, and Jakarta Stock Exchange

\section{PENDAHULUAN}

Pasar modal semakin besar perannya sebagai salah satu pendukung gerak roda dunia bisnis. Penyelenggaraan pasar modal mendorong percepatan aktivitas investasi yang sangat dibutuhkan oleh sektor riil. Pasar modal juga memberikan alternatif investasi yang sangat fleksibel bagi para investor. Sebagai salah satu alternatif investasi, investor membutuhkan informasi yang relevan untuk mendukung keputusan investasi. Salah satu informasi yang perlu dianalisis adalah aktivitas emisi surat berharga tambahan yang dilakukan oleh emiten pada periode setelah penawaran saham perdana atau biasa disebut IPO (Initial Pulic Offering).

Ada dua cara yang dapat dilakukan oleh perusahaan untuk menawarkan sahamnya kepada publik. Kedua cara tersebut adalah unseasoned securities dan seasoned securities (Meggison, 1997). Unseasoned securities adalah penawaran surat berharga kepada publik melalui mekanisme Initial Public Offering. Seasoned securities adalah surat berharga tambahan - diluar surat berharga yang telah beredar di masyarakat - yang ditawarkan kepada publik pada saat seasoned equity offering (SEO). Penawaran surat berharga tambahan ini dilakukan perusahaan untuk mendapatkan tambahan dana yang nantinya dimanfaatkan untuk membiayai kegiatan ataupun membayar hutang yang jatuh tempo.

Penjualan seasoned securities dapat dilakukan dengan beberapa cara. Perusahaan dapat menjual hak (right) kepada pemegang saham lama untuk membeli saham baru dengan harga tertentu. Cara ini disebut sebagai right issue. Cara yang lain, surat berharga tersebut dijual kepada investor melalui mekanisme second offering, third offering, dan seterusnya. Pemilihan mekanisme penjualan sangat tergantung pada kondisi maupun strategi perusahaan. Perusahaan yang kepemilikannya terkonsentrasi akan cenderung menggunakan mekanisme right issue untuk memperoleh tambahan dana (Eckbo and Masulis, 1992). 
Selain menggunakan mekanisme SEO, tambahan dana dapat juga diperoleh melalui pinjaman bank. Pada tingkat leverage tertentu, perusahaan akan cenderung lebih memilih SEO karena ada beberapa keunggulan dibandingkan pinjaman bank. Penawaran saham tambahan memerlukan biaya yang lebih murah. Bila pinjaman bank biasanya diikuti dengan penjaminan aktiva dan kewajiban membayar tingkat bunga tertentu, SEO tidak memberikan syarat tesebut.

Dalam proses SEO, perusahaan harus mempublikasikan prospektus penawaran yang berisi informasi keuangan maupun informasi lainnya untuk menarik publik melakukan pembelian. Pada kondisi ini, sangat mungkin apabila manajer memiliki informasi tentang perusahaan yang lebih banyak jika dibandingkan para investor (asimetri informasi). Ketimpangan ini menimbulkan kecenderungan pihak manajemen untuk melakukan manipulasi terhadap informasi yang dipublikasikan. Manipulasi ini berupa usaha meningkatkan kinerja perusahaan melebihi kinerja yang sesungguhnya. Usaha ini bisa dipahami karena pihak manajemen akan berusaha keras untuk menarik minat publik dengan menyajikan kinerja yang optimal melalui informasi keuangan yang dipublikasikan.

Informasi keuangan yang dipublikasikan perusahaan menggambarkan kondisi keuangan perusahaan. Meskipun alasan perusahaan mengeluarkan saham baru bervariasi sesuai dengan kondisi masing-masing, tetapi pada umumnya didasari oleh ketidakmampuan perusahaan menghasilkan dana yang mencukupi untuk mendanai operasi ataupun untuk pengembangan usaha (Byrne, 2002). Kondisi keuangan perusahaan yang memicu aktivitas SEO dapat diinterpretasikan dari informasi yang tersedia beberapa periode sebelumnya.

Ada sejumlah penelitian yang berupaya untuk membuktikan kecenderungan manajemen melakukan manipulasi informasi keuangan. Salah satu pendekatan yang dilakukan adalah dengan analisis kinerja perusahaan sebelum dan sesudah melakukan SEO. Penelitian yang dilakukan oleh McLaughin et a.l (1996) menganalisis cash flow pada periode sebelum dan sesudah SEO. Hasil penelitian menyimpulkan bahwa terjadi penurunan kinerja cash flow perusahaan sekitar $20 \%$ selama tiga tahun setelah penawaran. Temuan ini didukung penelitian Teoh et al. (1998) yang membuktikan adanya penurunan kinerja jangka panjang (3 tahun) sesudah dilakukannya SEO. Penelitian tersebut menggunakan rasio keuangan likuiditas, leverage, operating, dan profitabilitas sebagai proksi kinerja perusahaan. Teoh et al. (1998) juga menyatakan walaupun secara umum kondisi perekonomian memburuk, tapi penurunan kinerja perusahaan yang melakukan SEO ternyata lebih besar daripada yang tidak melakukan SEO. Hasil-hasil penelitian di atas mengindikasikan adanya upaya manajemen memanipulasi laba sebelum proses SEO, agar kinerja perusahaan pada saat penawaran tersebut kelihatan bagus.

Pendekatan lain untuk menjelaskan earnings management sebelum SEO dilakukan oleh Rangan (1998) dan Erickson and Wang (1999). Penelitian-penelitian ini memberikan alternatif penjelasan atas temuan earnings management seputar penawaran saham. Para peneliti ini menyajikan hipotesis bahwa para investor tidak memahami earnings management pada saat penawaran saham. Para manajer berusaha menunjukkan kinerja yang baik untuk mengantisipasi negosiasi harga pembelian saham oleh investor. Dengan demikian earnings management merupakan bentuk ekspektasi rasional yang perlu dilakukan untuk menarik minat investor. Pernyataan ini didukung oleh Shivakumar (2000) yang menyatakan bahwa earnings management dilakukan bukan didasari motivasi pembiasan informasi tetapi merupakan reaksi rasional untuk mengantisipasi perilaku pasar.

Temuan berbagai penelitian seputar penawaran saham tambahan, pada umumnya menunjukkan optimisme pasar terhadap prospek perusahaan yang mengeluarkan saham (Loughran and Ritter, 1997). Meskipun demikian Loughran and Ritter (1997) mengatakan bahwa masih perlu diadakan pengujian lebih lanjut untuk mengidentifikasi karakteristik yang dapat digunakan untuk memprediksi penurunan kinerja sesudah SEO. Secara khusus, karakteristik yang diperoleh diharapkan akan dapat digunakan untuk menjelaskan apakah penurunan kinerja perusahaan merupakan manifestasi akibat dari kinerja sebelum SEO.

Untuk kasus di Bursa Efek Jakarta, penelitian Harto (2001) dan Candy (2002) memberikan gambaran bahwa secara signifikan kinerja perusahaan yang melakukan SEO mengalami penurunan pada periode 3 tahun sesudah SEO. Harto (2001) mengukur kinerja yang meliputi likuiditas, leverage, operating, dan profitabilitas, sedangkan Candy (2002) mengukur kinerja keuangan dan kinerja operasional perusahaan yang melakukan SEO. Penelitian dilakukan dengan menggunakan model yang sama, yaitu dengan 
membandingkan kinerja sebelum dan sesudah SEO. Walaupun ditemukan bukti adanya penurunan kinerja yang signifikan setelah SEO, namun penelitian-penelitian tersebut belum memberikan penjelasan tentang faktor-faktor penyebabnya. Penelitian-penelitian tersebut hanya menduga adanya manipulasi pada periode sebelum SEO yang menyebabkan penurunan kinerja sesudah SEO.

Terkait dengan uraian tersebut di atas, penelitian ini dilakukan untuk membuktikan kebenaran dugaan Harto (2001) dan Candy (2002) tentang fenomena manipulasi informasi keuangan pada peristiwa emisi saham tambahan (SEO) di Bursa Efek Jakarta. Penelitian dilakukan dengan menganalisis kinerja perusahaan sebelum SEO (pre-SEO), untuk perusahaan yang terdaftar di Bursa efek Jakarta pada periode 1997-2002. Analisis dilakukan dengan membandingkan kinerja antara perusahaan yang melakukan SEO dengan perusahaan lain sejenis dan mempunyai ukuran sama yang tidak melakukan SEO. Asumsinya adalah, apabila perusahaan melakukan manipulasi, maka kinerja keuangan sebelum SEO tentunya secara rata-rata lebih tinggi dari perusahaan lain sejenis dan berukuran sama yang tidak melakukan SEO. Melalui penelitian ini diharapkan adanya pembuktian awal tentang kebenaran dugaan tersebut.

\section{TINJAUAN TEORITIS DAN PENGEMBANGAN HIPOTESIS}

\subsection{Seasoned Equity Offerings (SEO)}

SEO merupakan aktivitas emiten di pasar modal yang berupa penawaran sekuritas tambahan (seasones securities) kepada masyarakat. Penawaran ini dilakukan karena emiten sebagai perusahaan go public membutuhkan tambahan dana untuk membiayai kegiatan usahanya. Penawaran dapat dilakukan dengan dua cara (Megginson, 1997):

a. Menjual hak (right) kepada pemegang saham lama untuk membeli saham baru dengan harga tertentu (biasa dikenal sebagai right issue).

b. Menjual kepada setiap investor yang ingin membeli sekuritas baru melalui second offerings, third offerings dan seterusnya.

Perusahaan dengan kepemilikan terkonsentrasi cenderung menggunakan pilihan pertama untuk memperoleh tambahan dana. Right issue merupakan penawaran sekuritas baru yang memberi prioritas kepada pemegang saham perusahaan (stockholders) untuk membeli sekuritas baru tersebut pada harga tertentu dan saat tertentu pula. Dengan cara ini perusahaan mendistribusikan hak opsi kepada pemegang saham agar dapat memperoleh sekuritas baru dengan harga khusus. Tujuan penawaran ini adalah melindungi kepentingan pemegang saham perusahaan khususnya dalam melaksanakan hak preemptive (Hartono, 1998). Hak ini dilaksanakan agar pemegang saham lama tetap dapat mempertahankan proporsi kepemilikan sahamnya sama seperti sebelum SEO. Apabila pemegang saham tidak menggunakan haknya, maka saham dapat ditawarkan ke pasar.

Second offerings atau third offerings merupakan penawaran sekuritas tambahan langsung kepada masyarakat tanpa memberi hak istimewa kepada pemegang saham lama. Berbeda dengan proses penawaran saham perdana (IPO), dalam SEO seorang investor memiliki pedoman dalam menentukan harga saham, yaitu harga pasar saham tersebut yang telah beredar. Sekuritas hasil penawaran tambahan dinilai paling tidak sebesar harga pasar sekuritas yang telah beredar.

\subsection{Rasio Keuangan}

Rasio merupakan gambaran hubungan atau perimbangan (mathematical judgement) antara suatu jumlah tertentu dengan jumlah yang lain (Munawir, 1995). Sedangkan Riyanto (1995) menyatakan bahwa rasio merupakan alat yang dinyatakan dalam 'arithmethical term' yang dapat digunakan untuk menjelaskan hubungan dua data, dan jika dihubungkan dengan masalah keuangan maka akan menjadi data keuangan.

Ada bermacam-macam penggolongan rasio keuangan, namun demikian hanya beberapa golongan saja yang banyak digunakan. Golongan rasio tersebut meliputi: rasio likuiditas, leverage, aktivitas, profitabilitas, dan pertumbuhan. Dari tiap golongan tersebut dapat diperinci rasio-rasio yang terkait di dalamnya. 
a. Rasio Likuiditas; rasio yang dipergunakan untuk mengukur kemampuan perusahaan dalam memenuhi kewajiban jangka pendeknya. Rasio yang termasuk dalam golongan ini adalah current ratio dan quick ratio. Current ratio adalah rasio yang digunakan untuk mengukur kemampuan perusahaan dalam melunasi kewajiban lancar menggunakan aktiva lancar. Quick ratio adalah rasio yang digunakan untuk mengukur kemampuan perusahaan dalam melunasi kewajiban lancar menggunakan aktiva yang paling likuid (quick asset) berwujud kas, surat berharga, dan piutang.

b. Rasio Leverage; rasio yang dipergunakan untuk mengukur seberapa besar harta perusahaan diperoleh atau didanai dengan hutang. Rasio yang termasuk golongan ini antara lain adalah debt to equity ratio dan liabilities to total asset. Debt to equity ratio adalah rasio yang digunakan untuk mengukur proporsi hutang terhadap modal sendiri. Liabilities to total asset adalah rasio yang menjelaskan seberapa besar harta yang dimiliki perusahaan didanai dengan hutang.

c. Rasio Aktivitas; rasio yang dipergunakan untuk mengukur efektivitas perusahaan dalam menggunakan sumber daya yang terdapat dalam perusahaan. Beberapa rasio yang masuk dalam golongan ini adalah accounts receivable turnover dan inventory turnover. Accounts receivable turnover adalah rasio yang dipergunakan untuk mengukur perputaran dana yang tertanam pada piutang periode tertentu. Inventory turnover adalah rasio yang mengukur perputaran dana yang tertanam pada inventory.

d. Rasio Profitabilitas; rasio yang dipergunakan untuk mengukur efektivitas manajemen perusahaan secara keseluruhan, yang ditunjukkan dengan besarnya laba yang diperoleh perusahaan. Rasio yang masuk golongan ini di antaranya adalah net profit margin ratio, return on equity, dan return on asset. Net profit margin ratio adalah rasio yang mengukur perbandingan persentase laba bersih terhadap penjualan. Return on equity adalah rasio untuk mengukur keuntungan bersih yang diperoleh dari modal yang diinvestasikan oleh pemilik perusahaan. Return on asset adalah rasio untuk mengukur keuntungan bersih yang diperoleh dari harta perusahaan.

e. Rasio Pertumbuhan; rasio yang dipergunakan untuk mengukur pertumbuhan perusahaan di antara dua periode. Pertumbuhan yang dianalisis biasanya pertumbuhan laba, penjualan, modal, dan asset.

\subsection{Earnings Management dan SEO}

Dalam peristiwa SEO terjadi asimetri informasi antara manajer dan investor. Asimetri terjadi karena manajer dianggap lebih menguasai informasi mengenai kondisi perusahaan jika dibandingkan investor. Kondisi ini memberikan kemungkinan bagi manajemen untuk memunculkan sikap oportunistik, dalam wujud memanipulasi data yang dilaporkan sebelum dan saat penawaran dengan menggunakan discretionary accruals (Teoh et al., 1998). Sikap ini dikenal dengan istilah manajemen laba (earnings management).

Pada sejumlah penelitian tentang SEO (Jensen, 1986; Loughran and Ritter, 1997; Teoh et al. 1998; Harto, 2001 dan Candy, 2002), ada temuan yang menunjukkan penurunan kinerja penurunan perusahaan setelah SEO. Sejumlah dugaan muncul berkaitan dengan penurunan kinerja ini. Perusahaan sebenarnya tidak mengalami penurunan kinerja, tetapi kinerja kelihatan menurun karena pada periode sebelum SEO perusahaan telah melakukan pembiasan data sehingga seolah-oleh kinerja perusahaan kelihatan baik. Dugaan ini sangat beralasan karena perusahaan yang melakukan SEO pada intinya memerlukan tambahan dana untuk kegiatan usahanya. Tambahan dana ini mungkin dikarena perusahaan mengalami kesulitan keuangan untuk menutup kewajiban yang jatuh tempo.

Namun dugaan adanya motivasi negatif di balik aktivitas earnings management disanggah oleh Shivakumar (2000). Penelitian Shivakumar (2000) memperkaya khasanah diskusi dengan menunjukkan bahwa earnings management dilakukan bukan didasari motivasi pembiasan informasi tetapi merupakan reaksi rasional perusahaan untuk mengantisipasi perilaku pasar. Sebagai pihak yang menawarkan saham, perusahaan tentunya tidak akan mau menanggung resiko apabila sahamnya tidak laku. Dalam kondisi seperti ini sangat rasional apabila perusahaan menyajikan kondisi yang "menjanjikan" pada saat penawaran saham tambahannya.

Dugaan-dugaan yang mewarnai setiap penelitian SEO menunjukkan betapa sampai dengan saat ini SEO merupakan fenomena yang masih layak untuk dicermati. Banyak metode yang digunakan untuk menjelaskan fenomena yang terjadi di seputar peristiwa SEO. Salah satu metode yang biasa digunakan 
adalah pemanfaatan informasi akuntansi. Kondisi keuangan perusahaan yang memicu aktivitas SEO dapat diinterpretasikan dari informasi akuntansi yang tersedia beberapa periode sebelumnya. Dari uraian ini jelas sekali bahwa ternyata informasi akuntansi banyak berperan dalam menjelaskan fenomena yang terjadi di pasar modal.

\subsection{Hipotesis Penelitian}

Untuk memberikan arah penelitian, maka perlu dirumuskan hipotesis yang akan dijawab dalam penelitian ini. Didasarkan dugaan adanya earnings management oleh perusahaan yang melakukan SEO di BEJ (Harto, 2001 dan Candy, 2002) maka dirumuskan hipotesis penelitian sebagai berikut:

$\mathrm{H}_{\mathrm{A}}$ : Terdapat perbedaan kinerja perusahaan yang signifikan antara perusahaan yang melakukan SEO dengan yang tidak melakukan SEO pada periode sebelum SEO.

\section{METODA PENELITIAN}

\subsection{Definisi Operasional}

Agar cakupan penelitian tidak terlalu luas, maka dalam penelitian ini perlu diberikan definisi operasional dari variabel-variabel yang digunakan dalam penelitian.

a. Kinerja perusahaan yang dimaksud adalah kinerja keuangan yang meliputi rasio likuiditas, ungkitan (leverage), aktivitas, profitabilitas, dan pertumbuhan.

b. Seasoned Equity Offering didefinisikan sebagai emisi saham tambahan yang ditawarkan kepada publik ( public right issue).

c. Lembaga keuangan tidak dimasukkan sebagai sampel penelitian untuk menghindari dampak dari pengaruh regulasi tertentu yang bersifat khas yang dapat mempengaruhi variabel penelitian.

\subsection{Kerangka Penelitian}

Untuk memberikan landasan teoritis yang memadai bagi penelitian, diperlukan suatu kerangka pemikiran yang bersumber dari penalaran atas sejumlah teori dan temuan penelitian terdahulu yang ada. Kerangka pemikiran yang bersifat konseptual tersebut perlu dioperasionalisasikan agar terukur dan mudah diinterprestasikan. Oleh karena itu, kerangka konseptual yang digunakan dalam penelitian ini dapat digambarkan dengan model sebagai berikut:

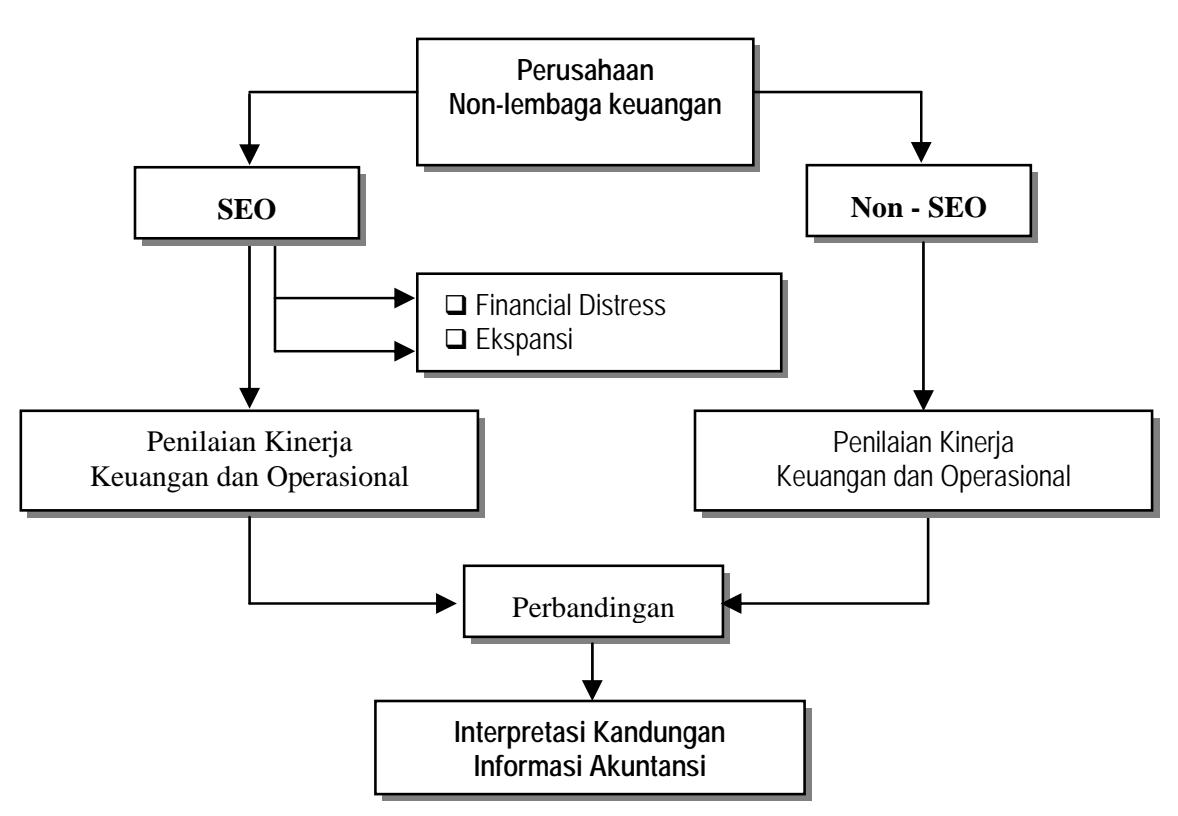

Gambar 1. Kerangka Penelitian 


\subsection{Variabel Penelitian}

Penelitian ini menggunakan variabel kinerja keuangan berbentuk rasio yang diadopsi dari penelitian Harto (2001) maupun Candy (2002). Rasio keuangan yang digunakan dalam penelitian ini adalah curent ratio $(\mathrm{CR})$, debt to equity ratio (DER), return on investment (ROI), operating profit margin (OPM) dan net profit margin (NPM).

\subsection{Data}

Data yang digunakan dalam penelitian ini adalah data sekunder berupa data keuangan perusahaan yang terdaftar dan melakukan right issue di BEJ. Aktivitas SEO yang digunakan sebagai sampel penelitian adalah SEO yang dilakukan dari tahun 1997 sampai 2002. Analisis dilakukan terhadap kinerja perusahaan 2 tahun sebelum SEO sehingga data yang dikumpulkan berupa rasio yang diperoleh dari laporan keuangan perusahaan yang dipublikasikan dengan jangka waktu 2 tahun sebelum SEO. Data bersumber dari Indonesian Capital Market Directory, Pusat Informasi Pasar Modal (PIPM) Semarang, maupun Pusat Referensi Pasar Modal yang diakses melalui website Bursa Efek Jakarta. Sampel perusahaan SEO yang dipilih adalah perusahaan non-lembaga keuangan.

\subsection{Penyampelan}

Dalam penelitian ini dilakukan dua kali penyampelan; pertama untuk menentukan sampel perusahaan yang melakukan SEO, dan yang kedua; menentukan sampel perusahaan pembanding yang tidak melakukan SEO.

\subsubsection{Sampel Perusahaan SEO}

Sampel diambil dari populasi perusahaan yang melakukan right issue pada periode 1997-2002. Right issue digunakan sebagai proksi SEO karena di Indonesia sebagian besar proses SEO dilakukan dengan cara menjual hak (right) kepada pemegang saham lama untuk membeli saham baru dengan harga tertentu. Dari populasi tersebut dilakukan seleksi dengan kriteria sebagai berikut:

a. Bukan merupakan bank dan lembaga keuangan lainnya.

b. Memiliki laporan keuangan yang dipublikasikan pada periode 2 tahun sebelum melakukan SEO.

c. Memiliki pembanding perusahaan yang tidak melakukan SEO.

Hasil seleksi selengkapnya ada di Lampiran 1. yang diringkas dalam Tabel 1.

Tabel 1.

Seleksi Sampel Perusahaan SEO Tahun 1997-2002

\begin{tabular}{lc}
\hline \multicolumn{1}{c}{ KETERANGAN } & JUMLAH \\
\hline SEO 1997-2002 & 120 \\
Dikurangi: & \\
$\mathbf{x}$ Bank dan Lembaga Keuangan & $(65)$ \\
$\mathbf{x}$ Data tidak tersedia & $(6)$ \\
$\mathbf{x}$ Tidak memiliki data pembanding & $(2)$ \\
Tersedia untuk diproses & 47 \\
\hline
\end{tabular}

(Keterangan lengkap lihat lampiran 1.) 
Setelah diperoleh sampel perusahaan yang melakukan SEO, langkah berikutnya adalah mengumpulkan data kinerja perusahaan. Data yang dikumpulkan berbentuk rasio keuangan dan diperoleh dari Indonesian Capital Market Directory (ICMD). ICMD yang digunakan adalah tahun 1996, 1999, dan 2001 untuk laporan keuangan 1995-2000 dan down load dari www.jsx.co.id untuk data tahun 2001. Data rasio keuangan selengkapnya ada pada lampiran 2.

\subsubsection{Sampel Perusahaan Non-SEO}

Penelitian ini akan menguji perbedaan kinerja antara perusahaan yang melakukan SEO dengan yang tidak melakukan SEO. Oleh karenanya, sampel yang diperoleh dari seleksi perusahaan SEO harus memiliki pembanding. Karena banyaknya perusahaan yang tidak melakukan SEO, maka harus dilakukan seleksi berdasarkan karakteristik yang dimiliki perusahaan SEO. Setiap perusahaan SEO dibandingkan dengan satu perusahaan pembanding dengan kriteria:

a. Terdaftar sebagai perusahaan publik pada periode 1997-2002.

b. Tidak melakukan right issue pada periode 1995-2002.

c. Bukan merupakan bank dan lembaga keuangan lainnya.

d. Memiliki kategori industri yang sama dan ukuran perusahaan sama yang didasarkân pada total assets atau market capitalization.

Rasio keuangan perusahaan pembanding yang digunakan juga diambil dari ICMD, sedangkan nilai market capitalization saat melakukan right issue diperoleh melalui BAPEPAM Jakarta. Berdasarkan kriteria di atas, akhirnya diperoleh 47 perusahaan pembanding yang dapat dilihat pada lampiran 3.

\subsection{Analisis Data}

Dalam penelitian ini akan dilakukan dua kali analisis, yaitu analisis deskriptif dan pengujian hipotesis. Analisis deskriptif dilakukan dengan menyajikan distribusi frekuensi, pengukuran tendensi sentral, dan pengukuran variasi kelompok. Selanjutnya data akan dianalisis untuk menginterpretasikan kecenderungan tertentu. Pada prinsipnya, analisis ini didasarkan pada serangkaian prosedur analitis untuk mendapatkan gambaran secara lengkap dari obyek yang diteliti.

Selanjutnya guna memperjelas kondisi obyek penelitian, akan dilakukan analisis statistik untuk menguji hipotesis. Pengujian dilakukan dengan membandingkan kondisi keuangan antara perusahaan yang melakukan SEO dengan perusahaan lain sejenis yang tidak melakukan SEO. Perbandingan dilakukan menggunakan uji beda.

Setelah dilakukan analisis data, perlu dilakukan interprestasi untuk menjelaskan hasil analisis data. Interprestasi dilakukan dengan didasarkan pada teori dan konsep ekonomi (economically meaningful).

\section{HASIL DAN PEMBAHASAN}

Bagian ini membahas proses penelitian dan hasil analisis yang diperoleh melalui serangkaian pengujian statistik. Analisis meliputi statistik deskriptif dan uji beda. Statistik deskriptif merupakan analisis kualitatif yang akan menguraikan nilai statistik variabel-variabel penelitian antara perusahaan yang melakukan SEO dan yang tidak melakukan SEO. Uji beda merupakan analisis kuantitatif yang digunakan untuk mengetahui apakah nilai rata-rata variabel kinerja perusahaan yang melakukan SEO secara signifikan berbeda dengan kinerja perusahaan yang tidak melakukan SEO.

\subsection{Gambaran Deskriptif Kinerja Keuangan Perusahaan Sampel}

Dari hasil seleksi sampel akhirnya diperoleh 47 data perusahaan yang melakukan SEO dan 47 perusahaan pembanding yang tidak melakukan SEO. Berikut ini disajikan nilai statistik deskriptif variabel kinerja perusahaan sampel yang disajikan dalam Tabel 2 . 
Tabel 2.

Statistik Deskriptif

\begin{tabular}{lrrrrr}
\hline & CR & DER & ROI & NPM & OPM \\
\hline Mean & \multicolumn{5}{c}{ SEO } \\
Median & 1,6880 & 12,4185 & 2,7760 & 5,0848 & 16,7207 \\
Std. Deviasi & 1,2550 & 1,6950 & 3,5500 & 6,4750 & 16,0900 \\
& 1,4735 & 76,9225 & 12,1248 & 54,5500 & 16,2542 \\
Mean & & & NON-SEO & \\
Median & 1,5091 & 2,2120 & 1,9728 & $-0,4778$ & 16,8009 \\
Std. Deviasi & 1,3700 & 1,6300 & 3,8000 & 4,0950 & 15,7400 \\
\hline
\end{tabular}

Sumber: Data diolah

Tabel 2 menyajikan nilai statistik dari variabel-varabel penelitian. Rata-rata (mean) kinerja perusahaan yang melakukan SEO hampir semuanya (CR, DER, ROI, dan NPM) menunjukkan nilai yang lebih tinggi jika dibandingkan dengan mean kinerja perusahaan yang tidak melakukan SEO. Hanya OPM yang menunjukkan mean kinerja perusahaan SEO sedikit di bawah mean kinerja perusahaan yang tidak melakukan SEO.

Nilai tengah (median) untuk semua rasio kinerja perusahan yang melakukan SEO memiliki nilai yang mendekati median dari perusahaan yang tidak melakukan SEO. Namun terlihat pula bahwa standar deviasi untuk tiap-tiap rasio sedemikian besar yang berarti terdapat penyimpangan yang besar dari nilai mean untuk setiap rasio keuangan. Hasil ini menunjukkan adanya sebaran data yang besar dalam setiap kelompok sampel, yang mungkin menjadi penyebab mengapa mean kinerja perusahaan SEO lebih tinggi dari mean kinerja perusahaan yang tidak melakukan SEO. Untuk memastikan dugaan adanya perbedaan secara deskriptif, berikutnya dilakukan uji beda secara statistik.

\subsection{Perbandingan Kinerja Keuangan Perusahaan SEO dan Non-SEO}

Penelitian tentang SEO di Indonesia menghasilkan temuan bahwa kinerja perusahaan setelah SEO cenderung mengalami penurunan jika dibandingkan dengan periode sebelum SEO (Harto, 2001 dan Candy, 2002). Temuan tersebut konsisten dengan hasil yang ditemukan pada penelitian di luar negeri seperti McLaughin et al. (1996), Lougran dan Ritter (1997), serta Teoh et al. ( 1997). Penelitian-penelitian tersebut menemukan adanya penurunan kinerja sesudah SEO dan menduga penyebabnya adalah adanya earnings management pada periode sebelum SEO. Manipulasi ini disebabkan manajer perusahaan menginginkan publik memberikan penilaian positif terhadap perusahaannnya dan akhirnya merespon penawaran saham tambahan. Namun manipulasi ini tidak dapat dilakukan terus-menerus pada periode-periode berikutnya. Akibatnya manajer akan menyajikan laporan yang normal, sehingga memunculkan kesan adanya penurunan kinerja dibandingkan periode sebelumnya.

Sejalan dengan dugaan tersebut, penelitian ini mencoba untuk mengetahui apakah perusahaan Indonesia yang melakukan SEO juga melakukan earnings management pada periode sebelum SEO. Penelitian dilakukan dengan membandingkan kinerja perusahaan yang melakukan SEO dengan yang tidak melakukan SEO. Asumsi yang digunakan adalah apabila perusahaan melakukan earnings management, tentunya kinerja keuangannya akan lebih tinggi jika dibandingkan dengan perusahaan lain sejenis pada periode amatan yang sama.

Sampel dalam penelitian ini berjumlah 47 perusahaan, dengan data tahunan masing-masing 2 tahun, sehingga jumlah data untuk tiap kelompok sampel berjumlah 94 item data. Dari tabel 2 terlihat bahwa standar deviasi dari rasio-rasio tersebut begitu besar sehingga bisa disimpulkan bahwa distribusi data tidak normal. Selain itu, data perusahaan pembanding dipilih sedemikian rupa mendekati kriteria perusahaan SEO. Dengan demikian dapat disimpulkan bahwa kelompok data perusahaan SEO berpasangan dengan non-SEO, 
sehingga pengujian dilakukan menggunakan Wilcoxon Ranks Test. Hasil pengujian selengkapnya dapat dilihat dalam Tabel 3.

Tabel3.

Hasil Wilcoxon Rank Test

Sumber: Lampiran 4

Tabel di atas menunjukkan hasil bahwa nilai Z pengujian semuanya mempunyai signifikansi $>0,05$ sehingga dapat disimpulkan tidak terdapat perbedaan kinerja yang signifikan antara perusahaan yang melakukan SEO dengan yang tidak melakukan SEO. Dengan demikian, simpulan atas hipotesis penelitian yang menduga bahwa kinerja perusahaan yang melakukan SEO lebih tinggi daripada kinerja keuangan dan operasional perusahaan yang tidak melakukan SEO pada periode sebelum SEO tidak dapat diterima (tolak $\mathrm{H}_{\mathrm{A}}$.

\subsection{Pembahasan}

Melihat hasil analisis kualitatif pada tabel 2 yang kemudian dilanjutkan dengan analisis kuantitatif, terdapat hasil yang bertolak belakang. Dalam tabel 2 terlihat bahwa mean kinerja perusahaan SEO secara umum jauh lebih tinggi dibandingkan mean kinerja perusahaan yang tidak melakukan SEO. Namun ternyata perbedaan yang tinggi tersebut secara statistik tidak signifikan. Hasil ini tentunya menimbulkan pertanyaan (1) mengapa mean dua kelompok yang sedemikian jauh berbeda, ternyata secara statistik tidak signifikan? dan (2) apakah mungkin dua kelompok sampel tersebut sebenarnya tidak mewakili obyek yang diteliti? Untuk menjawab pertanyaan tersebut, dilakukan analisis berdasarkan plot perbandingan dari kinerja kedua kelompok yang tersaji dalam tabel-tabel berikut.

Tabel 4.

\section{Scatter Plot Current Ratio Perusahaan Sampel}

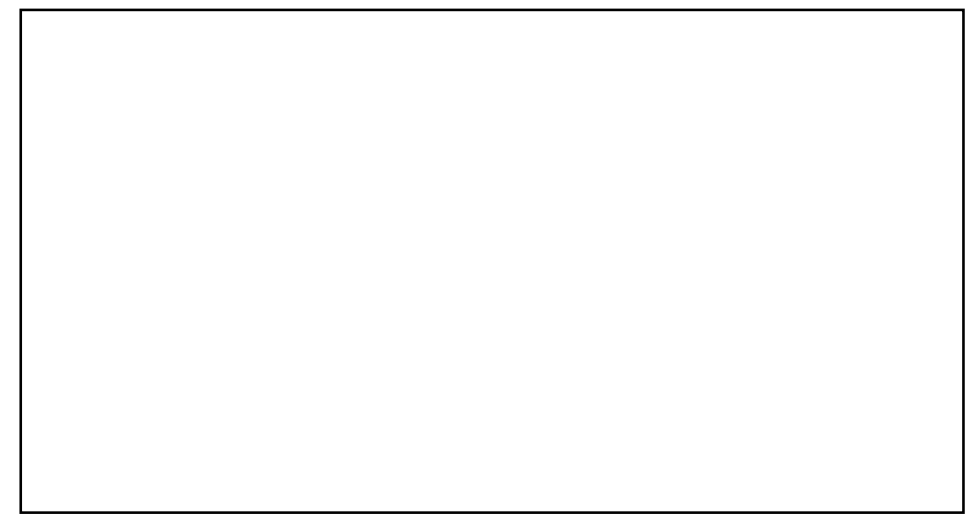


Tabel 5.

Scatter Plot Debt Equity Ratio Perusahaan Sampel

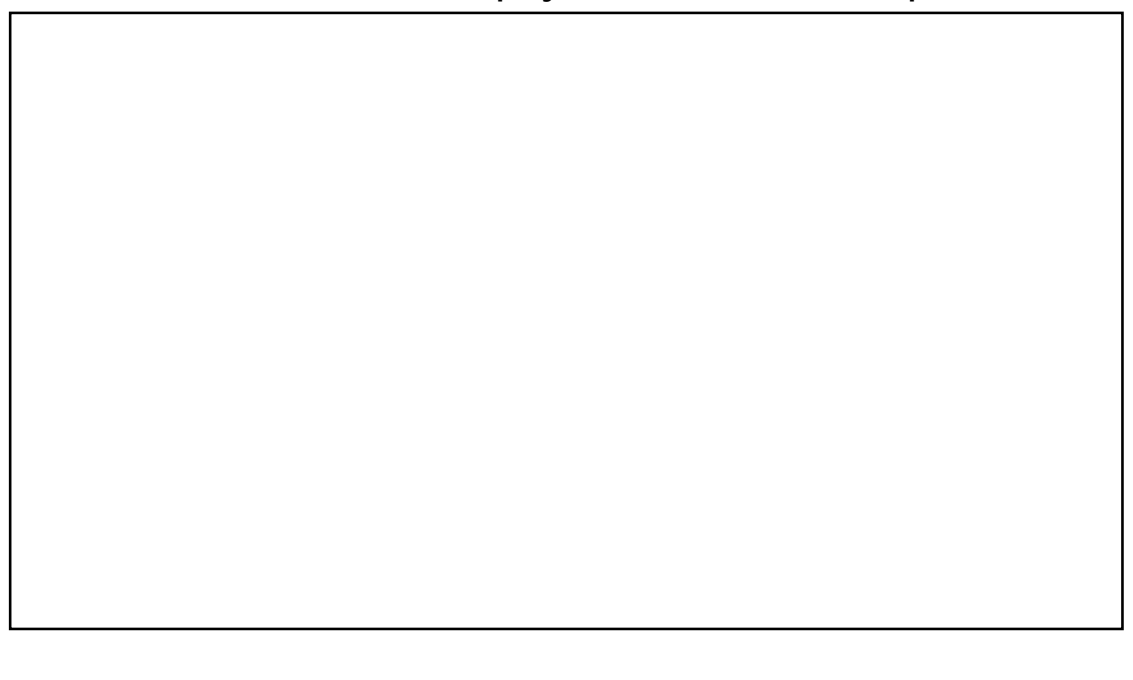

Tabel 6.

Scatter Plot Return On Investment Ratio Perusahaan Sampel

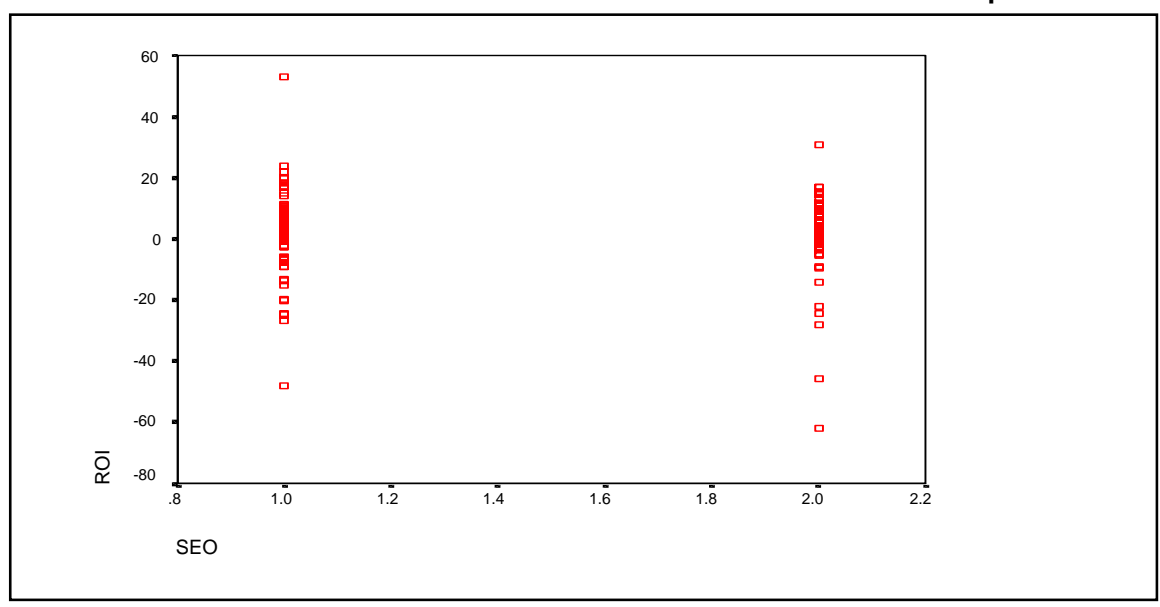

Tabel 7.

Scatter Plot Net Profit Margin Ratio Perusahaan Sampel

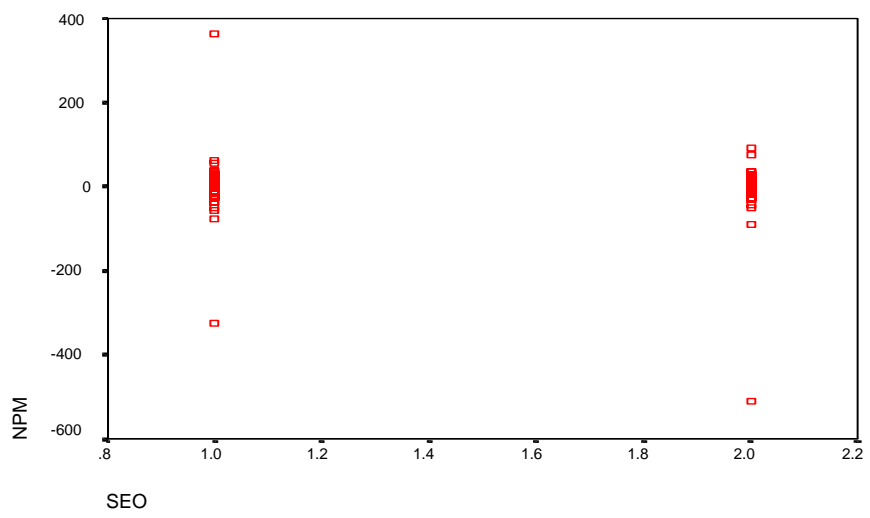


Tabel 8.

Scatter Plot Operating Profit Margin Ratio Perusahaan Sampel

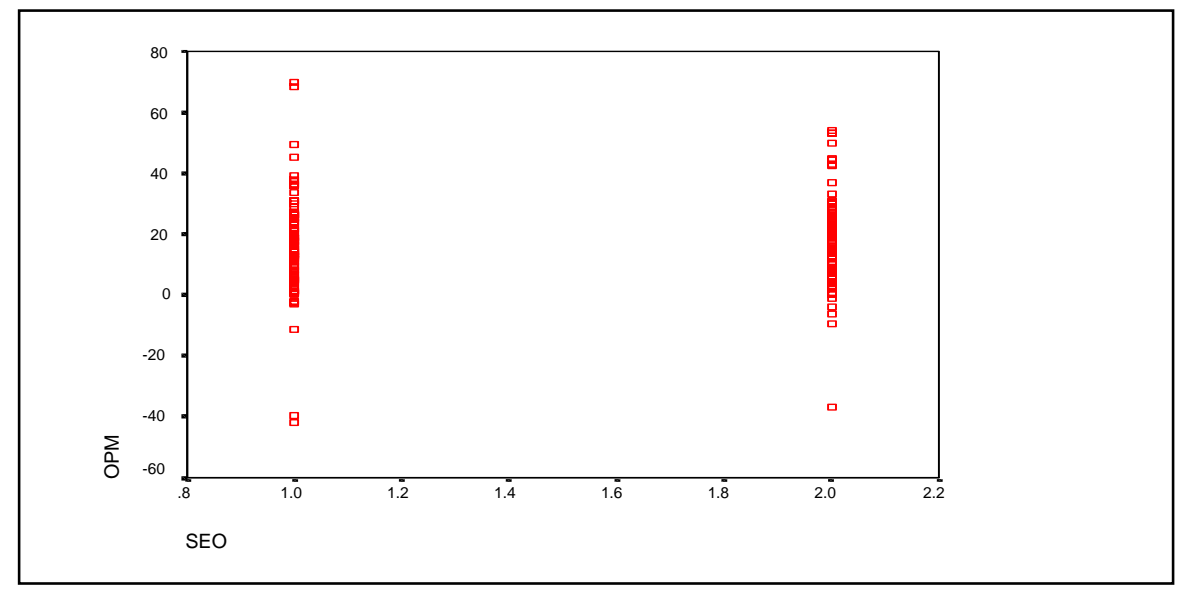

Dari tabel 4 - 8 dapat dilihat bahwa sebaran data perusahaan SEO (1.0) cenderung lebih luas jika dibandingkan perusahaan yang tidak melakukan SEO (2.0). Hal ini disebabkan adanya data yang jauh menyimpang (outliers) dari rata-rata dalam kelompok data. Namun penyimpangan ini sesungguhnya merupakan fenomena yang menarik dan dapat menjelaskan kemungkinan adanya earnings management pada perusahaan yang melakukan SEO.

Selain itu, dari tabel 4 - 8 juga dapat dilihat bahwa sebaran data antara perusahan yang melakukan SEO dan yang tidak melakukan SEO cenderung mengelompok pada rentang tertentu mendekati median. Hal ini menjelaskan mengapa tidak terdapat perbedaan kinerja keuangan dan operasi yang signifikan antara perusahan yang melakukan SEO dan yang tidak melakukan SEO. Mean kinerja perusahaan SEO yang lebih tinggi disebabkan adanya sejumlah perusahaan yang memiliki rasio kinerja yang jauh menyimpang dari mean kelompok (outliers). Perusahaan-perusahaan inilah yang mungkin sebenarnya melakukan praktik earnings management sebelum melakukan SEO. Dari temuan ini dapat disimpulkan bahwa secara umum kinerja perusahaan yang melakukan SEO tidak berbeda dengan yang tidak melakukan SEO.

\section{SIMPULAN}

Penelitian ini bertujuan untuk membandingkan kinerja perusahaan yang melakukan SEO dengan yang tidak melakukan SEO pada periode sebelum SEO. Penentuan tujuan tersebut didasarkan pada asumsi bahwa perusahaan yang melakukan SEO kemungkinan melakukan manipulasi sehingga kinerjanya lebih tinggi daripada yang tidak melakukan SEO. Hasil penelitian menunjukkan bahwa tidak terdapat perbedaan kinerja yang signifikan antara perusahaan yang melakukan SEO dengan yang tidak melakukan SEO. Dari hasil ini dapat dibuat dugaan bahwa kemungkinan tidak terdapat earnings management yang dilakukan perusahaan sebelum melakukan SEO.

Penelitian-penelitian terdahulu di luar negeri (Jensen, 1986; McLaughin et a.l 1996; Loughran and Ritter, 1997; Teoh et al. 1998) mengungkapkan adanya kecenderungan pihak manajemen untuk melakukan manipulasi terhadap informasi yang dipublikasikan sebelum melakukan SEO. Manipulasi ini berupa usaha meningkatkan kinerja perusahaan melebihi kinerja yang sesungguhnya (earnings management). Usaha ini bisa dipahami karena pihak manajemen akan berusaha keras untuk menarik minat publik dengan menyajikan kinerja yang optimal. 
Harto (2001) dan Candy (2002) mencoba meneliti fenomena tersebut di pasar modal Indonesia dengan membandingkan kinerja perusahaan sebelum dan sesudah SEO. Hasil penelitian menunjukkan penurunan kinerja sesudah dilakukannya SEO, yang kemudian disimpulkan bahwa hasil ini mengindikasikan adanya manipulasi laba sebelum dilakukannya SEO. Dengan dasar temuan ini dapat dibuktikan bahwa dugaan Harto (2001) dan Candy (2002) tentang adanya earnings management pada periode sebelum SEO belum terbukti. Namun demikian, dalam penelitian ini ditemukan bukti yang mengindikasikan bahwa praktik earnings management sebelum SEO mungkin hanya dijalankan oleh sejumlah kecil perusahaan publik.

Penurunan kinerja yang terjadi pada periode setelah SEO seperti temuan Harto (2001) dan Candy (2002) kemungkinan bukan karena manajemen tidak lagi melakukan earnings management, tetapi karena lebih disebabkan faktor-faktor perekonomian lainnya. Kemungkinan penyebab turunnya kinerja tersebut adalah: pertama, hasil yang diperoleh dari SEO kemungkinan digunakan untuk membayar hutang jangka pendek, sehingga perusahaan tidak memiliki dana lebih untuk meningkatkan kinerjanya. Kedua, kondisi krisis ekonomi yang masih melanda Indonesia sampai dengan periode 2002, membuat hutang perusahaan dalam mata uang asing yang tidak di-hedge membengkak jumlahnya.

Pada penelitian ini, kriteria perusahaan pembanding didasarkan pada perusahaan lain sejenis yang berasal dari industri sama dengan ukuran perusahaan yang sama. Kriteria ini menyebabkan tidak semua perusahaan SEO mendapatkan pembanding karena tidak adanya perusahaan pembanding yang memenuhi kriteria. Sebagai akibat, perusahaan yang tidak mempunyai pembanding tidak digunakan sebagai sampel penelitian. Hal ini menyebabkan jumlah sampel menjadi sedikit.

Selain itu, penelitian ini menggunakan sampel yang sebagian berasal dari periode krisis ekonomi di Indonesia. Secara umum krisis ekonomi berdampak pada sebagian besar perusahaan publik yang menyebabkan kinerja perusahaan menurun. Apabila perusahaan melakukan earnings management maka praktik ini dengan mudah akan terlihat oleh pasar sehingga âkan menyebabkan persepsi negatif di kalangan investor. Oleh karenanya hanya sedikit perusahaan yang melakukan earnings management pada periode krisis ekonomi.

Kelemahan lain pada penelitian ini adalah model analisis yang hanya membandingkan rasio keuangan antara perusahaan yang melakukan SEO dengan yang tidak melakukan SEO untuk mengindikasikan adanya praktik earnings management sebelum SEO. Temuan penelitian memang mengindikasikan adanya beberapa perusahaan yang melakukan praktik earnings management. Namun indikasi ini perlu diteliti lebih lanjut untuk dibuktikan kebenarannya karena perbandingan rasio belum bisa digunakan untuk mengindikasikan telah terjadinya praktik earnings management.

Sebenarnya ada banyak pengukuran yang dapat digunakan untuk mengidentifikasi variabel manipulasi dalam sebuah laporan keuangan. Salah satu model pengukur earnings management yang paling banyak digunakan adalah Jones (1991). Dengan adanya model tersebut, penelitian lebih lanjut dapat dilakukan untuk membuktikan adanya earnings management melalui identifikasi elemen laporan keuangan perusahaan yang melakukan SEO. Penggunaan model ini dapat memperbanyak jumlah sampel perusahaan yang melakukan SEO karena tidak dibutuhkannya perusahaan pembanding, sehingga hasil penelitian lebih dapat digeneralisasi karena lebih mewakili fenomena yang sesungguhnya.

Selain itu juga dimungkinkan untuk melakukan penelitian dengan menggunakan sampel pada periode sebelum atau sesudah krisis. Asumsinya, pada periode ini kondisi perekonomian relatif stabil, dan perusahaan publik akan berupaya menyajikan informasi yang terbaik untuk menarik minat investor. Kemungkinan yang akan dilakukan perusahaan untuk menarik minat investor salah satunya adalah dengan melakukan earnings management.

\section{DAFTAR PUSTAKA}

Byrne, H. J. (2002), Financial Management. Chartered Institute of Management Accountant; London, (Jul/Aug): 26. 
Candy (2002), "Analisis Kinerja Perusahaan yang Melakukan Seassoned Equity Offerings di Bursa Efek Jakarta", Skripsi Program Studi Akuntansi Fakultas Ekonomi Universitas Atma Jaya Yogyakarta (Tidak dipublikasikan).

Eckbo, B.E., and Masulis, (1992), "Adverse Selection and The Rights Offer Paradox." Journal of Financial Economics, 32: 293-332.

Erickson, M., and S. Wang, (1999), "Earnings Management by Acquiring Firms in Stock for Stock Mergers." Journal of Accounting and Economics, 27: 149-176.

Harto, (2001), "Analisis Kinerja Perusahaan Yang melakukan Right Issue di Indonesia", Proceeding Simposium Nasional Akuntansi IV, Jakarta.

Hartono, J., (1998), Teori Portofolio dan Analisis Investasi. Edisi pertama, BPFE; Yogyakarta.

Jensen, M.C. ,(1986), "Agency Costs of Free Cash Flow, Corporate Finance and Takeovers," American Economic Review (May): 654-665.

Jones, J.J., (1991), "Earnings Management During Import Relief Investigations." Journal of Accounting Research, vol. 29, no. 2 (Autumn):193-228.

Loughran, Tim., and Jay R. Ritter, (1997), "The Operating Performance of Firms Conducting Seasoned Equity Offerings." The Journal of Finance, Cambridge; Vol. 52, Iss. 5 (Dec): 1823.

McLaughlin, Robyn., Asem S., and Gopala K.V., (1996), "The Operating Performance Seasoned Equity Issuers: Free Cash Flow and Post Issue Performance." Financial Management, Vol. 25. Tampa; Vol. 25, Iss. 4 (Winter): 41.

Megginson, (1997), Corporate Finance Theory. Addison-Wesley Educational Publishers, Inc.

Munawir, S., (1995),Analisa Laporan Keuangan. Penerbit Liberty; Yogyakarta.

Rangan, S., (1998), "Earnings Management and the Performance of Seasoned Equity Offerings." Journal of Financial Economics, 50: 101-122.

Riyanto, Bambang, (1995), Dasar-Dasar Pembelanjaan Perusahaan. Edisi ke-empat, BPFE; Yogyakarta.

Shivakumar, L., (2000), "Do Firms Mislead Investors by Overstating Earnings before Seasoned Equity Offerings?" Working Paper, London Business School.

Teoh, Siew Hong., Ivo Welch., and T.J. Wong, (1998), "Earnings Management and the Underperformance of Seasoned Equity Offreings." Journal of Financial Economics. 50: 63-99. 